\title{
Sustainable Agriculture in Benin: Strategies for Applying the Chinese Circular Agriculture Model
}

\author{
Charles Nounagnon Gangnibo \\ School of Environmental Studies, China University of Geosciences (Wuhan) \\ 430074, Wuhan, China \\ E-mail: charlaco2000@yahoo.fr \\ Shenggao Cheng \\ School of Environmental Studies, China University of Geosciences (Wuhan) \\ 430074, Wuhan, China \\ E-mail: chengsg@cug.edu.cn \\ Lei Huang \\ School of Environmental Studies, China University of Geosciences (Wuhan) \\ 430074, Wuhan, China \\ E-mail: stoyuan@yahoo.com.cn \\ Antoine Sambou \\ School of Environmental Studies, China University of Geosciences (Wuhan) \\ 430074, Wuhan, China \\ E-mail: tonysambouegos@yahoo.fr
}

\begin{abstract}
Recently, many emerging economies try to follow the example of the West's industrialization by developing material-intensive production systems. As a solution to the environmental problems caused by this kind of economic growth, China is implementing the concept of Circular Economy by drawing on the experiences from Germany, Denmark and Japan. This concept in agriculture is called 'circular agriculture'. Benin through its Strategic Plan for Agricultural Sector Revival (PSRSA), wishes to attain poverty alleviation within short time (2008-2015). This study aimed to establish basic aspects required for Benin to adopt the circular agriculture which is in practice in China. Primary data from Government reports and interviews were used. The study shows how important agriculture is for food security in Benin. It also shows progress made by China in the path of Circular Economy in general and especially in circular agriculture. Through circular agriculture, Benin could achieve the goal of sustainable agriculture.
\end{abstract}

Keywords: Circular economy, Circular agriculture, Sustainable agriculture, China, Benin

\section{Introduction}

Human beings are dependent on agriculture for food, which is essential for their survival (Atkinson, et al., 2007). According to the World Bank, nearly 75 percent of people facing dire poverty (earning less than 1USD per day) in the developing world live in rural environments and rely on agriculture as their major source of food and income (NRC, 2008). In addition, the World agricultural production is still challenged by the world demand for food and industrial crops. This may explain why significant attention has been given to the question of whether agriculture, particularly modern agriculture, can maintain its current levels of production and those predicted for the near future. However, through its emphasis on high production, the industrial model has degraded soil and water, reduced the biodiversity that 
is a key element to food security, increased our dependence on imported oil, and driven more and more acres into the hands of fewer and fewer farmers, crippling rural communities (Earles, 2005). Moreover new technologies such as genetically engineered plants are not expected to be a major factor in food production increase in developing countries during the next two decades (Hazelle, 1995). Concerns also are growing about the long-term sustainability of agriculture. FAO estimates that some 850 million people worldwide are currently undernourished (FAO, 2008). According to the same institution the number of undernourished in developing countries will exceed 400 million in 2030. Therefore developing countries and the international development community are presently increasing and redirecting their resources in order to achieve various development objectives such as reductions in poverty, hunger and malnutrition (Fan, et al., 2008). In addition, consensus about the future demand growth will have to be met essentially by increasing the productivity of land already in cultivation, especially through yield increases (Cuffaro, 2003). As a result of the challenge to feed its growing population, developing countries have opted for agriculture development. Highly productive fertilizer and new technologies such as genetically engineered plants have been introduced over the past three decades (Gruhn et al., 2000). Unfortunately, over application of inorganic and organic fertilizer has led to environmental contamination of water resources and soils in developing countries (Gruhn et al., 1998). Furthermore, harsh climatic conditions, population pressure, land constraints, and the decline of traditional soil management practices have often reduced soil fertility (Stoorvozel and Smaling, 1990; Tandor, 1998). Sustainable agriculture ${ }^{1}$ is viewed as an alternative against threats from present kind of agriculture. Sustainable agriculture integrates the goals of environmental health, economic profitability, and social and economic equity (ESCAP, 2009).

Environmental problems and the daunting challenge of feeding the world's largest population with limited resources have led China to define ways and means of better aligning resource use with societal interests and environmental sustainability (OECD, 2001). One of these strategies to sustain China's agriculture is the 'circular agriculture'. Circular agriculture involves applying the principles of the Circular Economy ${ }^{2}$ to agricultural production. It is an entirely new concept and set of strategies, an improved approach to agricultural economy that addresses the coordinated development of populations, resources and the environment (Tang, et al., 2006). The implementation of this new concept has resulted in greater economic, environmental and social benefits in China (Tang, et al., 2006; Xu, 2006; Zhong, 2006).

Benin, like other developing countries is trying to develop and implement strategies for poverty reduction. Among those strategies, food security via sustainable agriculture is considered vital to any poverty alleviation strategies. Then, after an initial 'Strategy for Poverty Reduction (2003-2005)', a second strategy called 'Growth Strategy for Poverty Reduction (SCRP)' for the period 2007-2009 was formulated. Benin has also launched the 'Strategic Plan of Agricultural Sector Revival' called PSRSA' in 2008 (MAEP, 2008). The challenge of this plan is to make Benin an agricultural power and food safe by 2015 .

The application of this agricultural modernization plan (PSRSA) foresees changes in the cropping system in Benin such as widespread use of machines and fertilizers, large-scale exploitation of farmland and so forth. Furthermore, cooperation between China and Benin is growing more and more especially in the agricultural field (presence of Chinese agricultural technicians in Benin) and in the field of scientific research (grant of scholarships to Benin's students by China). Hence, there is a need for Benin to learn from China about circular agriculture on its way to modernize its agriculture sector. This has advantages for a developing country to feed its growing population without causing damage on environment and threatening life of the world population.

This study aimed to establish basic aspects required for Benin to adopt the circular agriculture currently in practice in China. To date, China's experience in circular agriculture is reviewed and Benin's agricultural situation has been analyzed taking into account both the situation of the past as that envisaged in the future through the PSRSA.

\section{Environmental settings}

This study is based on two case studies, China and Benin. China was used as study area to explore and grasp the potentials, challenges and lessons about 'circular agriculture'. Benin is the targeted area for implementation of the concept. Therefore the details given about environmental settings are only of Benin.

\subsection{Location of Benin}

The Republic of Benin is located in West Africa, between $6^{\circ} 30$ and $12^{\circ}$ North Parallels and $1^{\circ}$ and $3^{\circ} 40$ East Meridians. It is bordered by the Republic of Niger to the North, Burkina Faso to the North-East, the Atlantic Ocean to the South, Togo to the West and the Federal Republic of Nigeria to the East. It covers an area of $112622 \mathrm{Km}^{2}$.

\subsection{Climate}

The climate is hot and wet, with an annual rainfall mean ranging from about $700 \mathrm{~mm}$ (North) to $1500 \mathrm{~mm}$ (South-East) and the average air temperature of about $27^{\circ} \mathrm{C}$. Most certainly, geographical elements such as the stretching of the territory in latitude, the existence of the Atacora Mountain and the orientation of the coastline bring about a slight difference in the climate pattern. 


\subsection{Geology, soils and hydrology}

Benin belongs to a leveled Western African unit constituted of primary rocks supporting relatively recent sedimentary stratifications. There are three units or zones: mountainous zone, coastal zone and plateau zone.

There are five main types of soils in Benin: tropical ferruginous soils (cover $80 \%$ of the area of Benin), ferralitic soils ( $8 \%$ of the area of the country), hydromorphic soils ( 5 to $8 \%$ ), vertisols ( $5 \%$ of the territory), and minerals soils. The ferralitic soils are today very threatened because they are occupied by nearly half of the population of Benin. In 2005, the land use in Benin shows that the arable land is $23.53 \%$, the permanent crops $2.37 \%$ and other $74.1 \%$.

The hydrographical network comprises $3048 \mathrm{Km}$ of water courses and more than $333 \mathrm{Km}^{2}$ of water areas (lakes and lagoons) located in the South part of the country.

\subsection{Demographic characteristics}

Benin's population was estimated at 8294941 inhabitants in July, 2008 with an annual growth rate which remains stagnated at $2.8 \%$. The population is unequally distributed on the national territory and is concentrated for more than $35 \%$ on the southern part, which only represent $10 \%$ of the country area. It is however young (around $50 \%$ are below the age of 15 years) and characterized by a high female proportion (around 52\%). The population constitutes the main force for agriculture: employs over $45 \%$ of the active population.

\subsection{Economic and political context}

Economy growth which was negative before 1991 has increased during the past decade and reached $6.1 \%$ in 2001 before dropping down to $4.5 \%$ in 2009 because of international market situation and recent economic crisis.

The new institutional order introduced through the historical Conference of the Active Forces of Nation held in February 1990, the materialization of which is in progress, has made of Benin an easier destination and hoisted it at the vanguard of "New Democracies". Benin has got the experience of peaceful, fair and transparent elections.

\section{Materials and method}

\subsection{Literature review}

\subsubsection{Circular economy}

The Circular Economy concept was introduced in China to address environmental degradation and resources scarcity associated with rapid economic development (Geng, et al., 2008). Based on the experiences of certain countries such as Germany, Japan, Denmark, China declared Circular Economy as a national strategy (Yin, 2006). China has conducted trial work for Circular Economy at three levels: Cleaner Production at enterprise level; build ecological industry parks (EIPs) in the industrial areas; and develop provincial and municipal experiment with circular economy. To date, a number of economic and informational instruments have been used to implement Circular Economy principles. These include: pollution levies, environmental taxes and eco-labeling, environmental management tools (such as co-generation and wastewater recycling and reuse), Life Cycle Assessments (LCAs) and "3Rs" (Reduction, Reuse and Recycling) of waste (Ren, et al., 2005; Lu, et al., 2005; Hinton, 2008). Additionally, environmental management systems such as ISO 14001 have been used.

1998: Circular Economy was proposed for the first time by Scholars.

1999: Eco-industrial parks were launched.

2002: Cleaner Production Promotion Law and Environmental Impact Assessment were passed.

2004: The National Development Reform Commission (NDRC) was appointed for the duty of promoting Circular Economy principles.

2005: Law on pollution prevention and control of solid waste was passed.

2006: The National Economic and Social Development Plan ( $11^{\text {th }}$ Five-Year Plan) was put forth and Green public procurement was put into official guidelines.

2007: Draft of the Circular Economy Law was discussed by standing Committee of the $10^{\text {th }}$ National People's Congress.

\subsubsection{Circular agriculture}

The application of the principles of Circular Economy to agriculture is called 'circular agriculture'. Circular agriculture is an entirely new concept and set of strategies, an improved approach to agricultural economy that addresses the coordinated development of populations, resources and the environment. At its core are the principles of sustainable development, Circular Economy and extended production chains (Geng, et al., 2008). Many factors are involved, which can be enumerated as follows: technological innovations and organizational reforms; optimization of the internal and production structures of agri-ecological systems and extension of production chains (Tang, et al., 2006). Others are 
multilevel in nature, which include circular utilization of energy; maximal utilization of biomass energy resources; utilization of every material link in the production process; promotion of clean production and conservation-minded consumption; stringent control of harmful inputs and waste production; maximum reduction of pollution and ecosystem destruction. At the same time, efforts are made to increase the value of each stage of production and to improve the quality of the human environment so that production and producers alike take their place in a benign agri-ecological circle conducive to the harmonious development of the agricultural industry and rural communities alike. As a low-input, high-recycling, high-efficiency, high-technology and industrialized set of practices, 'circular agriculture' is distinct from conventional or traditional agriculture and represents a revolution in the sector (Tang, et al., 2006).

\subsubsection{Some achievements}

Compared with developed countries (Germany, Japan, and Denmark), the achievements made in China about Circular Economy in general and circular agriculture in particular, are meager. Among the successes of implementation include conserving water, materials, energy and land (Geng, et al., 2008; Li, et al., 2009). China has now had almost a decade of experience in developing and implementing a Circular Economy concept. Chosen as a demonstration city, Dalian has implemented the Circular Economy strategy as a means of conserving water, materials, energy and land (Geng, et al., 2008).

The implementation of circular agriculture in Linquan, County of Anhui Province which features linkage of forest products, grasses, livestock, fungi, biogas and fertilizers, results in greater economic and social benefits. It has proven particularly valuable in the handling of cattle manure, for which three downstream channels have been found, in the production of mushrooms, methane and foodstuffs respectively (Tang, et al., 2006).

The same model developed in the Eastern Xihu district of Wuhan, for example, achieves standardized, large-scale production of raw materials by integrating industry, locality and farmers in a system that brings in orders of RMB 60 million annually to local cattle farmers. At the same time, manures and liquid animal wastes are processed in a composting facility that uses modern fermentation and odor-reduction technology to produce high-quality organic fertilizers that bring in a further RMB 10 million of income (Tang, et al., 2006).

Also the Ecological Industrial Park model developed in the Sujiatun district of Shenyang, results in great success. The external framework consists of the various systems governing grape cultivation, wine production, anti-oxidant bio-engineering, bio-fertilizers production and environmental protection, such that the respective functions of the grape, manufacturing and agro-tourism industries are combined in a single entity that manifests itself in a closed-loop eco-economic network.

The Circular Economy in Suzhou (Jiangsu Province) High-Tech Development Zone's economic growth mode has changed from investment expansion in the past to efficiency advancement (China Daily, 2005). The industrial water recycle rate has also been raised from 65 per cent to 75 per cent and the utilization rate for industrial waste also increased from 73 per cent to 80 per cent. Moreover, a collection and classification garbage system in the zone has been established according to the same journal. Also, the air quality has met the nation's second-level standard for the past two consecutive years while the zone's sewage disposal rate remained at 100 per cent and the zone's green cover-age also rose from 32 per cent to 40 per cent on a yearly basis.

However, there are much to be done by China to achieve the same success as developed countries like Germany and Japan. Besides, the 11th Five-Year Plan for National Economic and Social Development of China believes that: "energy consumption per unit GDP will be cut down by $20 \%$ and total discharge of major pollutants $\left(\mathrm{COD}\right.$ and $\left.\mathrm{SO}_{2}\right)$ will be reduced by $10 \%$ in 2010 compared with that of 2005 " by implementing Circular Economy strategy (Xu, 2006).

\subsection{Data sources}

This study is based on primary data which have been substantiated by secondary sources. An multidisciplinary approach was used, so a wide array of fields was incorporated. Also, it was acknowledged that using multiple sources of evidence can be important in revealing different perceptions of the same phenomena (Yin, 2003; Hinton, 2008). The data used in this study have been collected between February and May 2009 in Benin. Primary data have been collected from Government reports and interviews. The information collected came from two sources: The Ministry of Agriculture (towards the Strategic Plan of Agricultural Sector Revival-PSRSA) and interviews involving some agricultural experts. Data collected focused on productions from previous years, forecasts of future (PSRSA) and problems related to past agricultural system in Benin. Virtually no data obtained on the impacts of agriculture on the environment. This gap of data was filled by interviewing some experts, which gave us a clear view on the matter. These experts are from the Ministry of Agriculture, IITA (International Institute of Tropical Agriculture) and Faculty of Agricultural Sciences. Semi-structured interviews have been carried out with the aim to get a better understanding, experiences and interests of the interviewees. Interviews were carried out by phone calls and electronic mails. Due to fact that the subject material is not very sensitive and the answers are not likely to change according to mood or emotional circumstances (Kvale, 1996), there is no problem by substituting a live, phone conversation with written communication (emails). The literature 
review was focused on Chinese 'circular agriculture' situation so as to get a deeper understanding of the concepts and theories related to Circular Economy. This literature review also involves the use of secondary data on both China and Benin. These secondary data are related to China's progress about Circular Economy, agriculture contribution to pollution in Benin, land use and so forth. Although, this approach is not popular but was the best way due to the limited resources (time and money), and distance between researchers (China) and respondents (in Benin).

Analytical technique

The data have been analyzed by using descriptive statistics such as means, minimums, maximums, standards deviation, as well as the Bivariate Correlation. This correlation aims to determine the relationships between the variables (acreage and yield, fertilizer input and soil degradation), to know how the variables are distributed. SPSS 13.0 software has been used for that purpose. Charts and histograms have been drawn using Microsoft Office Excel.

\section{Results and discussion}

\subsection{Importance of agriculture in Benin}

The contribution of agriculture to the economy of Benin is not negligible. Agriculture contribution to Gross Domestic Product has evolved from $33.1 \%$ in 1995 to $32.6 \%$ in 2005 with an average rate of $35.3 \%$ over the period (Figure 1). Agriculture is the second largest sector contributor to the economy of Benin behind the service sector. Table 1 shows the descriptive statistics on the agriculture contribution to the Gross Domestic Product (GDP) by sector. In the eleven years (1995 to 2005) taken into account in this study, the minimum in terms of contribution to GDP is 31.90 while the maximum is 38.40 with a mean of 35.31 and a Standard Deviation of 2.54 .

The analysis on the evolution of the cropping areas of some major crops (Figure 2) allows us to make the observations below:

1) An upward trend in the cropping areas of all major crops.

2) Some crops have evolved faster than others (case of maize and cashew nut) throughout the period (1995 to 2005).

3) Other crops have grown in size at varying rates over a period of the decade (case of rice).

4) The cultivation of cotton on the other hand has declined significantly in terms of area between 1997 and 2000.

The sharp increase in the maize cropping area is the result of the widespread cultivation to meet growing demand from national and regional markets for human consumption and industry (poultry feeding). As for the cashew nut, it is justified by a strong international demand. Regarding the cultivation of rice, it is being promoted to reduce national dependence vis-à-vis Asian imports. It is within this framework that was launched the promotion of NERICA rice, rice that can grow on all soil types. With regard to cotton, the cropping areas have evolved at a contrasted rhythm correlatively to the conjuncture of the market and Government incentives. The area experienced a significant growth in 1997 and 2002 due to the substantial increase in the prices paid to producers by the Government. But the gloomy international market was not always possible to maintain high prices or reduce input costs, which fully justifies the years of decline.

The situation described above is showed in Tables 2, 3 and 4 that present the correlations between the cropping areas and yields obtained over the period 1995-2005. Tables 2 and 3, show a significant positive correlation at the level of 0.05 for maize and cashew nut whereas it is a negative correlation for cotton.

\subsection{Agriculture and environment}

In many developing countries poverty and environment degradation are often related (WCED, 1987). It is known that the use of land for agricultural production is one of the strongest factors affecting environmental quality (Brady and Weil, 2002; Liu, et al., 2005; Zhang, et al., 2007; Oyekale, 2008).

Figure 3 shows an increasing utilization of fertilizer from 1994 to 2002 and a relative stabilization between 2004 and 2006. Although the rate of chemical fertilizer use in Benin remains low compared to other countries in the region, this could potentially present a long-term danger to the environment.

Besides the correlation fertilizer-soil degradation (Table 5) is significant at the 0.01 level. All experts interviewed on this subject agree that the greater the use of chemical fertilizers greater the risk of soil degradation. Furthermore, other studies have shown in Benin a close link between soil degradation and cultural practices (Olanrewaju, et al. 2007; Igué, 2008). The use of 'Endosulfan' pesticide in Benin was linked to significant health concern. 'Endosulfan' was widely used in cotton farming in Benin. Following dozens of farmers and their family falling sick or being exposed to it, some studies had concluded the health consequences to be closely related to 'Endosulfan' (Glin, et al., 2006).

Figure 4 shows the role of agriculture in environmental pollution in Benin. From a communication presented by the Environment Department in 2001, agriculture alone accounts for about 70\% greenhouse gas emissions (MEHU, 2001). Thus, special attention should be paid to projects in Benin. 


\subsection{Strategic Plan for Agricultural Sector Revival (PSRSA)}

Agriculture is an essential component of the economies of West Africa. In Benin, agriculture employs about $45 \%$ of active population and contributes to over $35 \%$ of Gross Domestic Product (Figure 1).

However, agriculture suffers from many problems including low productivity and correspondingly high prevalence of poverty. The land available for agriculture is also underused. The Strategic Plan for Agricultural Sector Revival (PSRSA) aims at improving the performance of agriculture in Benin to make it able to ensure permanent food security and contribute to economic and social development of the country. Thus the Strategic Plan for Agricultural Sector Revival is a part of the Millennium Development Goals.

The analysis of figure 5 allows us to see the facts of the goals of this plan. Significant growth is envisaged for the main crops. In terms of productivity corn could increase from 841000 tons in 2005 to 14000000 tons in 2011. Similarly rice productivity expected to increase from 60000 tons to 180000 tons whilst cotton would increased from 190000 to 600 000 tons. Some crops may even surpass the double of their productivity of 2005 (such as pineapple). The growth in production shown implies an increased cultivatable land and fertilizer input (see Tables 2 and 3). Furthermore the variable fertilizer-soil degradation was positively correlated at the 0.01 level (Table 5). Still the planned investments under the plan for modernization of agriculture indicate an increase in all crops with widespread use of machines and fertilizers. However there is indication that the highly production based on fertilizer and seed technologies introduced over the past three decades may be reaching a point of diminishing returns (Bouis, 1993; Cassman, et al., 1995). It appears from the following analysis the risk of soil degradation and even pollution of the environment will exist when this plan will be implemented. Nonetheless both the over and under application of fertilizer and the poor management of resources damages the environment (Gruhn, et al., 2000). It is therefore important for the agricultural engineers, environmental experts, soilists and all in charge of the implementation of PSRSA to seek for strategies to minimize the risk of environmental degradation.

\subsection{Strategies for circular agriculture implementation in Benin}

Several requirements are necessary in implementing circular agriculture in Benin (figure 6).

However more researches need to be done about Circular Economy in general and especially about circular agriculture. These researches will help to appropriate the concept, to understand all the details about it, other countries experiences, and the methodological approach for a total success of its implementation in Benin. It is important that the implementation of circular agriculture strategy need to be done by taking into account Benin's socio-economic and environmental situation. Benin will therefore need to keep on sending students and researchers to China and even other countries like Germany, Japan etc. to learn more (in theories and practice) about circular agriculture.

Secondary, an appropriate legal environment needs to be created so as to implement:

- $\quad$ Natural resources related legislation and policies (water resources, land resources, mineral resources, and energy).

- Laws, regulations and policies on environmental protection and comprehensive utilization of resources (much have been already done in this area: Law 87-16 about Water Code of the Republic of Benin; Law 98-030 about the Framework Law on the Environment in the Republic of Benin and so forth) and Cleaner Production.

- $\quad$ Legislation and policies on production and consumption areas.

- Legislative recommendation for 'circular agriculture' implementation.

Finally follow the principles of 'Cleaner Production' enterprises to come to ecological parks where the circular agriculture initiative will be done. Also financial effort must be made by Benin to the acquisition of 'clean technologies' (environmental-friendly technologies). This strategy must be first experienced at city level for five years at least before being adopted at national level. This could help to know how its works in aim to make some recommendations for its extension.

\section{Conclusion}

This study has showed how important is agriculture for food security and poverty alleviation in Benin. It has also proven the desire of Benin Government to make of Benin an agricultural power in West Africa through the program called 'PSRSA'. Although environmental degradation related to agriculture is not very noticeable in Benin, the risk of environmental degradation exists with the new plan of agricultural modernization. For this reason, strategies must be adopted to avoid the nightmare experienced by several countries that were formerly engaged in an intensive agricultural production. China who is experiencing successfully in circular agriculture strategy could serve as a model in Benin for sustainable agriculture promotion. The implementation of circular agriculture in Benin requires laws and policies establishment, agricultural infrastructures and technologies development up to the challenge and many researches. For this end, farmers, institutions, and Government all have an important role to play in sustaining agricultural productivity. 
This could help the country to feed its growing population without causing damage on environment and threatening life of the world population. However more researches still needed to deepen the conditions for implementing this strategy in Benin given the limitations of our research.

\section{References}

Atkinson, G., Dietz, S., and Neumayer, E. (2007). Handbook of sustainable development. Edward Elgar Publishing, Inc., Great Britain by MPG Books Ltd, UK. ISBN 9781843765776 (pp. 362-375).

Bouis, H. E. (1993). Measuring the sources of growth in rice yields: Are growth rates declining in Asia? Food Research Institute Studies Vol. XXII No 3, 305-330.

Brady, N. C. and Ray R. W. (2002). The nature and Properties of Soils (13 ${ }^{\text {th }}$ ed). Prentice Hall, New Jersey, USA. ISBN-10: 013048038X.

Cassman, K. G., De Datta, S. K., Olk, D. C., Alcantara, J., Samson, M., Descalsota, J., and Dizon, M. (1995). Yield decline and the nitrogen economy of long term experiments on continuous, irrigated rice systems in the tropics. In Soil management: Experimental basis for sustainability and environmental quality, ed. R. Lal and B. Stewart. Boca Raton, Fla., USA: CRC Press (pp.181-222).

China Daily (2005). Circular Economy: key to zone's success, published at May 16, 2005. [Online] Available at http://app1.chinadaily.com.cn/fortune2005/ft050516p11n.pdf . ( June 28, 2009).

Cuffaro, N. (2003). Population, Economic Growth and Agriculture in Less Developed Countries. Published in the Taylor \& Francis e-Library, ISBN 0-203-10310-6 Master e-book ISBN (pp. 133-147).

Earles, R. (2005). Sustainable Agriculture: An Introduction. A Publication of ATTRA, the National Sustainable Agriculture Information Service revised by Paul Williams, NCAT Program Specialist (pp: 1-4). [Online] Available: www.attra.ncat.org/attrapub/PDF/sustagintro.pdf (May 20, 2009).

Fan, S., Johnson, M., Saurkar, A., and Makombe, T. (2008). Investing in African Agriculture to Halve Poverty by 2015. Published by INTERNATIONAL FOOD POLICY RESEARCH INSTITUTE, IFPRI Discussion Paper 00751, 1-21.

FAO (2008). The state of food and agriculture. Food and Agriculture Organization of the United Nations, Rome, 2008 (pp. 71-78).

Geng, Y., Zhu, Q., Doberstein, B., and Fujita, T. (2008). Implementing China's circular economy concept at the regional level: A review of progress in Dalian, China, Waste Management (2008), 1-7. doi:10.1016/j.wasman.2008.06.036.

Glin, L., Kuiseu, J., Thiam, A., Vodouhê, D., Dinham, B., Ferrigno, S. (2006). Living with Poison: Problems of Endosulfan in West African cotton growing systems. PAN UK. [Online] Available: http://www.panuk.org/Projects/Cotton/Resources/index.html\#panuk (May 20, 2009).

Gruhn, P., Goletti, F., and Roy, R. (1998). Proceedings of the IFPRI/FAO workshop on plant nutrient management, food security, and sustainable agriculture: The future through 2020. Washington, DC, and Rome: IFPRI and FAO.

Gruhn, P., Goletti, F., and Yudelman, M. (2000). Integrated Nutrient Management, Soil Fertility, and Sustainable Agriculture: Current Issues and Future Challenges. International Food Policy Research Institute, Washington D.C. ISBN 0-89629-638-5 (pp. 1-21).

Hazell, P. (1995). Technology's contribution to feeding the world in 2020. In Speeches made at an international conference. Washington, DC: International Food Policy Research Institute.

Hinton, J. (2008). Is the circular economy ambitious enough? A look at incorporating PSS (product-service systems) into China's leapfrog development strategy. International Institute for Industrial Environmental Economics; Lund University. Master dissertation (pp 3-6).

Igué, A. M. (2007). Impact of land use effect on chemical and physical soil characteristics in Colline Department of Benin. INRAB, 1-12. [Online] Available: http://www.rivertwin.de/assets/igue_abstract_icld4.pdf (May 20, 2009).

Kvale, S. (1996). Interviews: An Introduction to Qualitative Research Interviewing. London: Sage Publications.

Li, H., Bao, W., Xiu, C., Zhang, Y., Xu, H. (2009). Energy conservation and circular economy in China's process industries, Energy (2009), 1-9. doi:10.1016/j.energy.2009.04.021.

Liu, X. B., Liu, J. D., Xing, B. S., Herbert, S. J., Meng, K., Han, X. Z. and Zhang, X. Y. (2005). Effects of long-term continuous cropping, tillage and fertilization on soil organic carbon and nitrogen of black soils in China. Comm.Soil.Sci., 36(9-10): 1229-1239.

Lu, X., Wang, S., and Hu, J. (2005). Government interventions in developing a circular economy- what can China learn from Sweden? International Business Program. Kristianstad University. Master dissertation (pp 7-37). 
MAEP (2008). Strategic Plan of Agricultural Sector Revival (PSRSA) in Benin. Government Report. MAEP, Republic of Benin. (pp: 10-31; 73-100).

MEHU (2001). First national communication of the republic of Benin to the framework convention on climate change. Ministry of Environment, of Habitat and Urbanism. [Online] Available: http://unfecc.int/resource/docs/natc/bennc1e.pdf (May 2, 2008).

National Research Council (2008). Emerging Technologies to Benefit Farmers in sub-Saharan Africa and South Asia. Committee on a Study of Technologies to Benefit Farmers in Africa and South Asia. The National Academies Press 500 Fifth Street, N.W. Washington, DC 20001. PP 19-24. [Online] Available: http://www.nap.edu/catalog/12455.html

OECD (2001). Environmental Indicators for Agriculture, volume 3. Paris: OECD Publications Service. (pp. 197-386).

Olanrewaju, L., Gaiser, T., and Nuga, B. (2007). Estimation of Potential Soil Losses on a regional Scale: A Case of Abomey-Bohicon Region. Benin Republic. Agricultural Journal 2(1): 1-8, 2007.

Oyekale, A. S. (2008). Land Degradation, Soil Conservation Practices and Poverty Incidence in Southwestern Nigeria. Agricultural journal 3(6): 482-487.

Ren, Y. et al. (2005). Policy and legal framework for promoting circular economy in China. China Population, Resource and Environment Journal 15, 131-136 (in Chinese).

Stoorvogel, J. J., and Smaling, E. M. E. (1990). Assessment of soil nutrient depletion in sub-Saharan Africa. Report 28. Volumes 1-4, Wageningen, The Netherlands: The Winand Staring Centre.

Tandon, H. L. S. (1998). Use of external inputs and the state of efficiency of plant nutrient supplies in irrigated cropping systems in Uttar Pradesh, India. Washington, DC and Rome: International Food Policy Research Institute and Food and Agriculture Organization of the United Nations.

Tang, H., and Yin, C. (2006). Models and strategies for the development of circular agriculture in china. Workshop on Environment, Resources, and Agricultural Policies in China 19-21 June 2006, Beijing, 1-10. [Online] Available: http://www.oecd.org/dataoecd/5/8/36786150.pdf (May 2, 2009).

United Nations Economic and Social Commission for Asia and the Pacific. (2009). Sustainable agriculture and food security in Asia and the pacific. Published by UN-ESCAP. (pp: 10-13). [Online] Available: http://www.unescap.org. (June 10, 2009).

World Commission on Environment and Development. (1987). WCED: Our common future-The Brundtland Report. Oxford: Oxford University Press.

Xu, Q. (2006). Developing Circular Economy and Establishing a Sustainable Production \& Consumption System. State Environmental Protection Administration, China. Conference on the Marrakech Process: November 22, 2006.

Yin, C. (2006). Principles of Circular Economy, Implications and Strategic Directions of Circular Agriculture. Compilation of the Chinese Academy of Agricultural Sciences, 83-88.

Yin, R. K. (2003). Case study research- Design and methods, $3^{\text {rd }}$ ed. US: Sage Publications.

Zhang, X. Y., Sui, X. Y., Zhang, X. D, Meng, K. and Herbert, S. J. (2007). Spatial variability of nutrient properties in black soil of northeast China. Pedosphere, 17: 19-29.

Zhong, T., Huang, X., Li, L., and Wang, C. (2006). Comprehensive Assessment of Regional Circular Economy Development Based on Efficiency of Resource \& Environment: A Case Study of Jiangsu Province. Chinese Journal of Population, Resources and Environment 2006 Vol. 4 No.1, 55-63.

\section{Notes}

Note 1: Sustainable agriculture is one that produces abundant food without depleting the earth's resources or polluting its environment. It is the agriculture that follows the principles of nature to develop systems for raising crops and livestock that are, like nature, self-sustaining.

Note 2: The Circular Economy further aims at improving the ecological efficiencies of production and reproduction activities, and maximizing economy output with minimized resource and energy consumption, so that the economic, environmental and social benefits could be harmonized and sustainable production and consumption patterns accomplished. 
Table 1. Showing descriptive statistics of agriculture contribution to Benin GDP (Source: Benin Department of Agriculture).

Descriptive Statistics

\begin{tabular}{|l|r|r|r|r|r|}
\hline & \multicolumn{1}{|c|}{$\mathrm{N}$} & Minimum & Maximum & \multicolumn{1}{c|}{ Mean } & Std. Deviation \\
\hline Agriculture & 11 & 31.90 & 38.40 & 35.3182 & 2.54040 \\
Industry & 11 & 13.40 & 14.60 & 13.8091 & .37803 \\
Service & 11 & 47.70 & 54.70 & 50.8727 & 2.60465 \\
Valid N (listwise) & 11 & & & & \\
\hline
\end{tabular}

$\mathrm{N}=$ Number of years

Table 2. Showing correlation between cropping area and yield: case of maize (Source: Benin Department of Agriculture).

\section{Correlations}

\begin{tabular}{|ll|r|r|}
\hline & & \multicolumn{1}{|c|}{ Acreage } & \multicolumn{1}{c|}{ Yield } \\
\hline Acreage & Pearson Correlation & 1 & $.873^{\star}$ \\
& Sig. (2-tailed) & & .010 \\
& $\mathrm{~N}$ & 7 & 7 \\
\hline Yield & Pearson Correlation & $.873^{\star}$ & 1 \\
& Sig. (2-tailed) & .010 & \\
& $\mathrm{~N}$ & 7 & 7 \\
\hline
\end{tabular}

*. Correlation is significant at the 0.05 level (2-tailed).

$\mathrm{N}=$ Number of years

Table 3. Showing correlation between cropping area and yield: case of cashew nut (Source: Benin Department of Agriculture).

\section{Correlations}

\begin{tabular}{|ll|r|r|}
\hline & & \multicolumn{1}{|c|}{ Acreage } & \multicolumn{1}{|c|}{ Yield } \\
\hline Acreage & Pearson Correlation & 1 & $.874^{\star}$ \\
& Sig. (2-tailed) & & .010 \\
& $\mathrm{~N}$ & 7 & 7 \\
\hline Yield & Pearson Correlation & $.874^{\star}$ & 1 \\
& Sig. (2-tailed) & .010 & \\
& $\mathrm{~N}$ & 7 & 7 \\
\hline
\end{tabular}

${ }^{*}$. Correlation is significant at the 0.05 level (2-tailed).

$\mathrm{N}=$ Number of years 
Table 4. Showing correlation between cropping area and yield: case of cotton (Source: Benin Department of Agriculture).

\section{Correlations}

\begin{tabular}{|ll|r|r|}
\hline & \multicolumn{1}{|c|}{ Acreage } & \multicolumn{1}{|c|}{ Yield } \\
\hline Acreage & Pearson Correlation & 1 & .227 \\
& Sig. (2-tailed) & & .625 \\
& $\mathrm{~N}$ & 7 & 7 \\
\hline Yield & Pearson Correlation & .227 & 1 \\
& Sig. (2-tailed) & .625 & \\
& $\mathrm{~N}$ & 7 & 7 \\
\hline
\end{tabular}

$\mathrm{N}=$ Number of years

NB: About the structure of these outputs (tables 2, 3, 4 and 5), notice that the upper portion of each cell identifies the correlations between variables accurate to three decimals; the middle portion indicates the significance of each corresponding correlation; and the lower portion records the number of subjects or elements involved in each correlation.

Table 5. Showing correlation between fertilizer input and soil degradation (Source: Survey data 2009).

\section{Correlations}

\begin{tabular}{|ll|r|r|}
\hline & & Soil \\
& & FertilizerInput & Segradation \\
\hline Fertilizerlnput & Pearson Correlation & 1 & $.998^{\star \star}$ \\
& Sig. (2-tailed) & & .000 \\
& $\mathrm{~N}$ & 6 & 6 \\
\hline SoilDegradation & Pearson Correlation & $.998^{\star \star}$ & 1 \\
& Sig. (2-tailed) & .000 & 6 \\
& $\mathrm{~N}$ & 6 & \\
\hline
\end{tabular}

**. Correlation is significant at the 0.01 level (2-tailed).

$\mathrm{N}=$ Number of experts interviewed

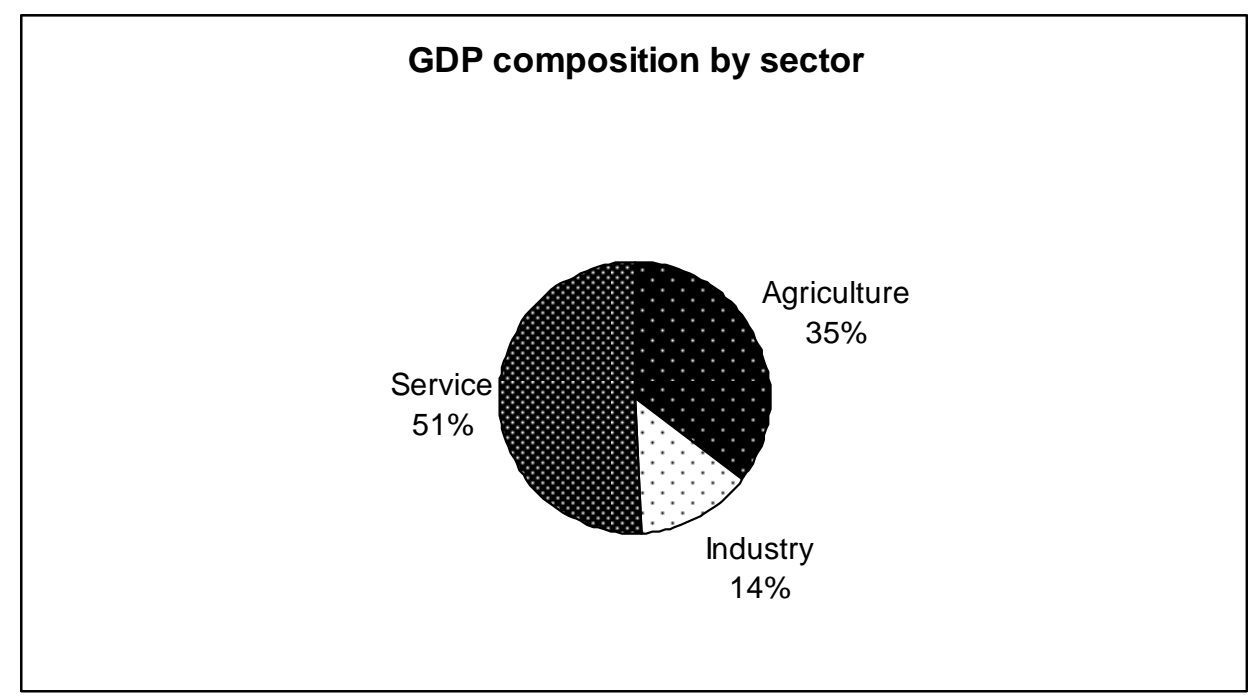

Figure 1. Showing agriculture contribution to GDP in Benin (Source: Benin Department of Agriculture) 


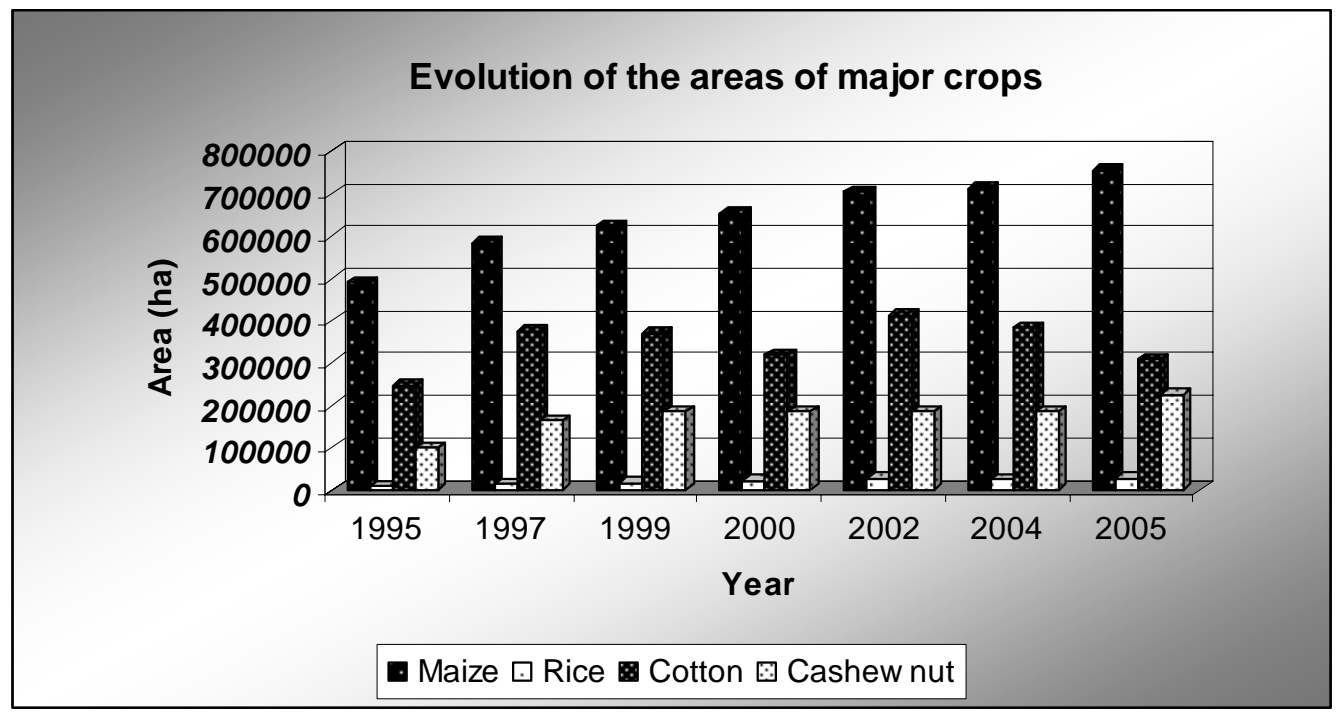

Figure 2. Showing the cropping areas evolution in Benin (Source: Benin Department of Agriculture).

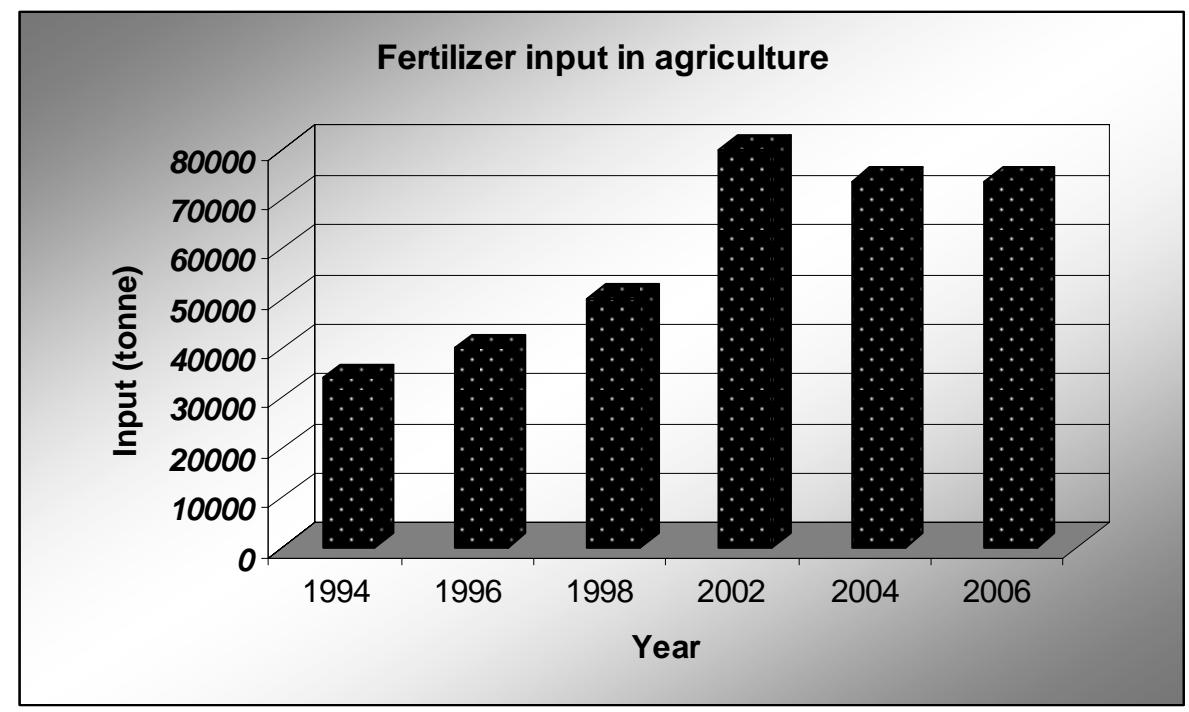

Figure 3. Showing fertilizer input in agriculture from 1994 to 2006 in Benin (Source: Benin Department of Agriculture).

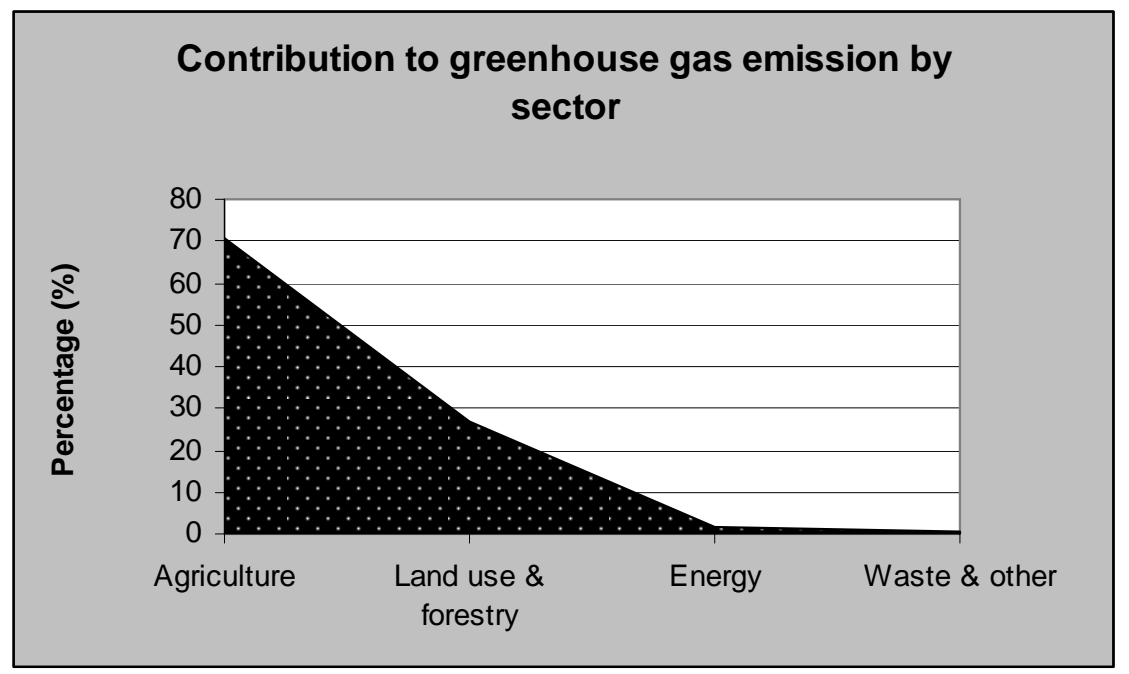

Figure 4. Showing agriculture contribution to environmental pollution in Benin (source: MEHU, 2001). 

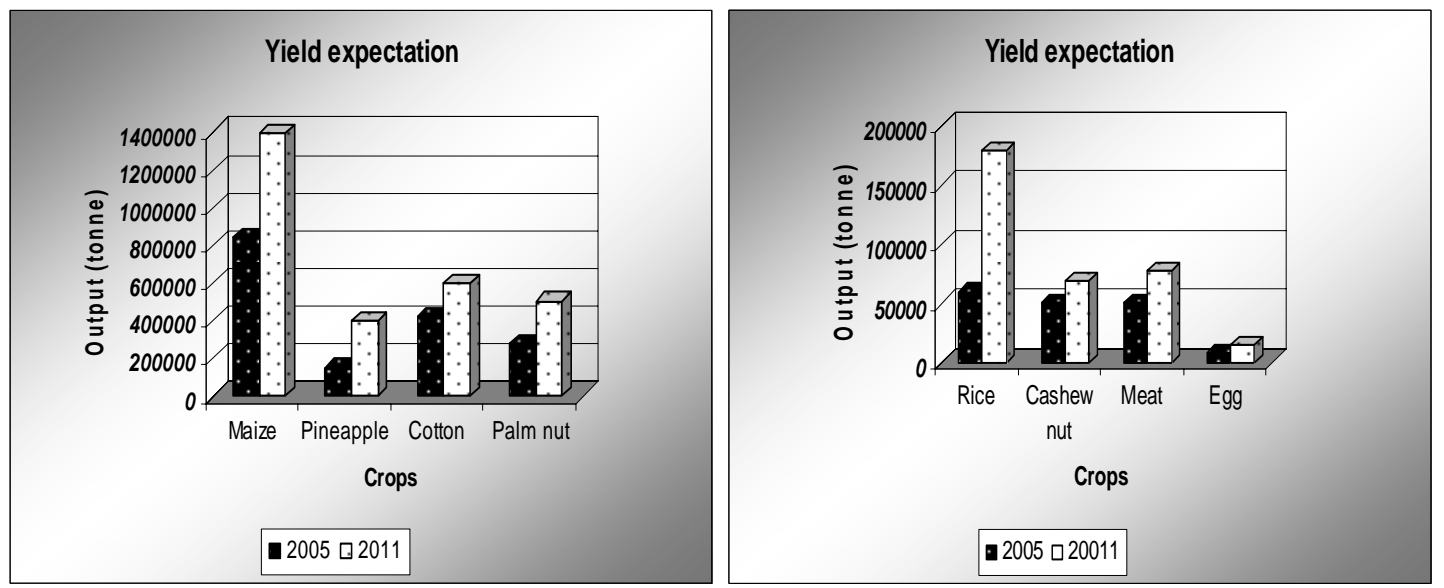

Figure 5. Showing PSRSA crops yields for 2005 and expectations for 2011 (Source: Benin Department of Agriculture).

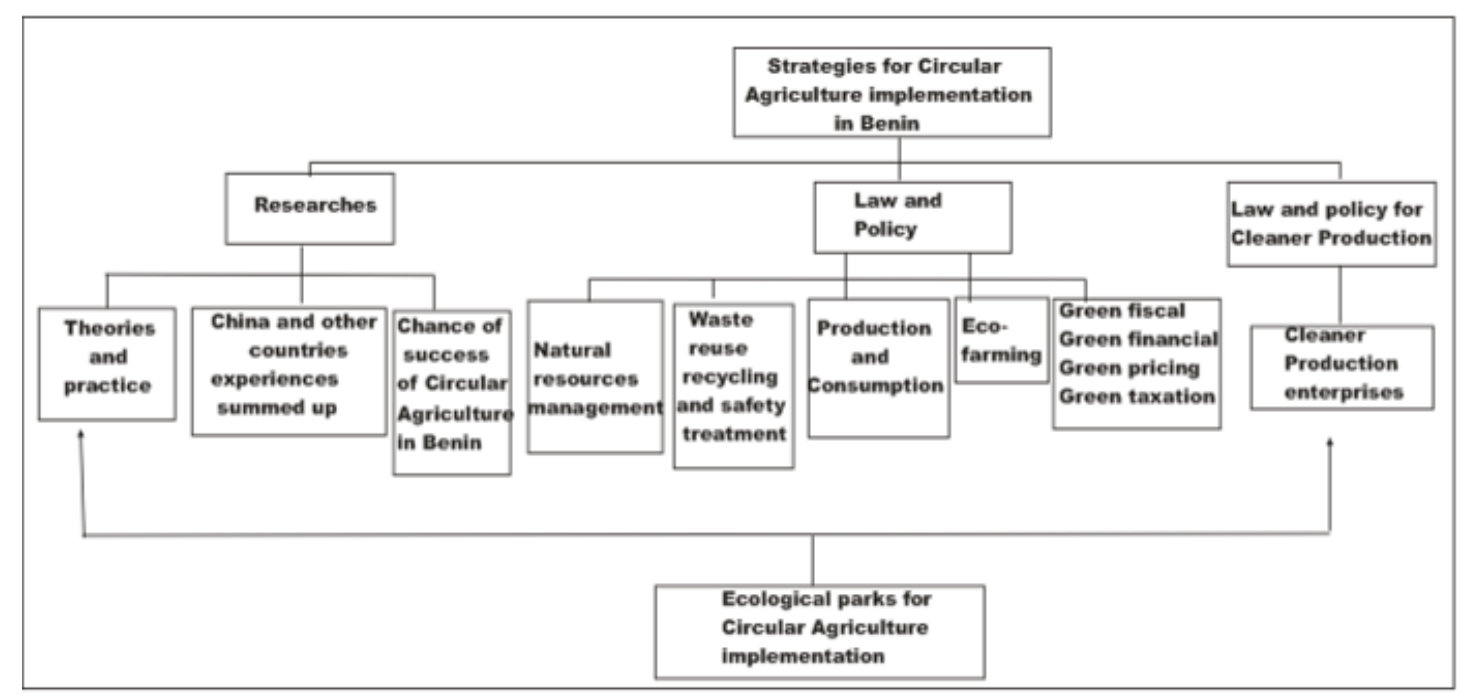

Figure 6. Showing conceptual framework for circular agriculture implementation in Benin 